DOI: 10.2478/v10014-008-0010-9

Agrovoc descriptors: musa (bananas), bananas, greenhouse crops, plant nematodes, nematoda, parasites, disease surveys, epidemiology, identification, greece

Agris category codes: H10

COBISS Code 1.03

\title{
Plant parasitic nematodes associated with banana crop in Crete, Greece
}

\author{
Emmanuel A. TZORTZAKAKIS ${ }^{1}$
}

Received September 14, 2007; accepted March 31, 2008.

Delo je prispelo 14. septembra 2007, sprejeto 31. marca 2008.

\section{ABSTRACT}

This is a report on the presence of Meloidogyne spp., Helicotylenchus multicintus and Pratylenchus goodeyi in roots of banana crops in Crete.

Key words: greenhouse crop, root-knot nematodes, lesion nematodes, spiral nematodes

\section{IZVLEČEK}

\section{PARAZITSKE OGORČICE RASTLIN UGOTOVLJENE V NASADU BANANOVCEV NA KRETI V GRČIJI}

To je poročilo o najdbi parazitskih ogorčic Meloidogyne spp., Helicotylenchus multicintus in Pratylenchus goodeyi v koreninah bananovcev na Kreti.

Ključne besede: bananovci, gojenje $v$ rastlinjaku, ogorčice

\section{INTRODUCTION}

Banana plantations in Crete occupy approximately 63 ha allocated in four areas with the main varieties being Cavendish, Grand Nain and Williams (data from the Banana Growers' Cooperative of Crete for the 2005-2006 growing season). The crop is mainly cultivated in greenhouses and in most cases conventional pest management practices are applied. Nematodes are a major pest of banana crop worldwide (Gowen and Queneherve, 1990). In Crete, a nematological survey on the most representative banana growing areas done in 1990 and 1991 revealed the presence of Meloidogyne javanica, Helicotylenchus multicinctus and Pratylenchus goodeyi (Vovlas et al., 1994).

\footnotetext{
1 Nematology Researcher., PhD., Plant Protection Institute, National Agricultural Research Foundation, PO BOX 2228, 71003, Heraklion, Crete, Greece. e-mail: etzortza@her.forthnet.gr
} 
In the work described here, the nematode species found in banana roots from samples brought in the Nematology Lab, Plant Protection Institute of Heraklion, by growers during the last 10 years are reported.

\section{MATERIALS AND METHODS}

Nematodes were extracted only from roots. Roots with lesions and necrotic areas were thoroughly washed from adhering soil and chopped into small pieces, which were spread on plastic sieves partially immersed in dishes with water. Endoparasitic migratory nematodes move outside from the root and are collected in water. For identification, they were prepared in slides, which were microscopically examined.

In cases of root galls, the roots were cut longitudinally and observed in a stereoscope for presence of females and egg masses of root-knot nematodes (Meloidogyne spp.). No attempts were made to identify these nematodes to species level.

\section{RESULTS AND DISCUSSION}

Nematodes are widespread in banana plantations of Crete, farmers are aware of their existence and conventionally manage them through annual applications of organophosphate / carbamate nematicides (personal communication with growers and agrochemical distributors). As banana is considered a high value crop in Crete, it is subjected to a great input of fertilizers, agrochemicals and water supply. Under these cropping systems, the problem of nematodes in reducing plant growth and yield may not be obvious; therefore, there are neither data estimating crop loss in banana plantations in Crete due to nematode attack nor a cost benefit of nematicide application. In the period 1995-2006 only 20 growers brought samples with nematode infection in the lab in cases where plants had early flowering, low production or did not respond to fertilizers. In all cases the spiral nematode Helicotylenchus multicinctus, the lesion nematode Pratylenchus goodeyi and the root-knot nematode Meloidogyne spp either alone or in coexisting populations were found. Almost in all cases, most of the nematode infected roots were deteriorated due to infection by other microorganisms, something that has been previously reported (Vovlas et al., 1994). An order in the frequency of the nematode species can not be determined, as in some cases it was observed that roots coming from different plants from the same greenhouse contained different nematode species.

The root systems infected by root-knot nematodes were heavily galled with galls at root tips (Figure 1). Roots infected by lesion and spiral nematodes indicated extensive black necrosis of epidermal and cortical tissue (Figures 2, 3) which are typical of nematode infection (Gowen and Queneherve, 1990; Vovlas et al., 1994). In our observations no discrimination could be done between root damage caused by lesion or spiral nematodes. Morphometrics of adults of $P$. goodeyi and $H$. multicinctus were within the range presented in species description (Siddiqui, 1973; Machon and Hunt, 1985).

It is concluded that the nematological problems of banana crop in Crete remain the same to these presented 16 years ago. In the meantime the system of banana 
planting has been changed. Growers are using now in vitro propagated plantlets instead of suckers removed from mother plants. That has significantly restricted the nematode dissemination through propagating material. However land is intensively used without crop rotation and the in vitro derived healthy plants are usually established in nematode infested fields. Furthermore, root-knot nematodes become a serious problem in young plantations established in greenhouses where vegetables have been previously grown (Figures 1,4).

\section{REFERENCES}

Gowen, S.R., Queneherve, P., 1990. Nematode parasites of bananas, plantains ans abaca. In: Plant Parasitic Nematodes in Subtropical and Tropical Agriculture. M. Luc, R.A Sikora and J. Bridge (eds). CAB International pp. 431-460.

Machon, J.E., Hunt, D.J., 1985. Pratylenchus goodeyi. C.I.H. Descriptions of Plant-parasitic nematodes. Set 8, No. 120.

Siddiqui, M.R., 1973. Helicotylenchus multicinctus. C.I.H. Descriptions of Plant-parasitic nematodes. Set 2, No. 23.

Vovlas, N., Avgelis, A., Goumas, D., Frisulo, S., 1994. A survey of banana diseases in sucker propagated plantations in Crete. Nematologia mediterranea 22: 101-107.

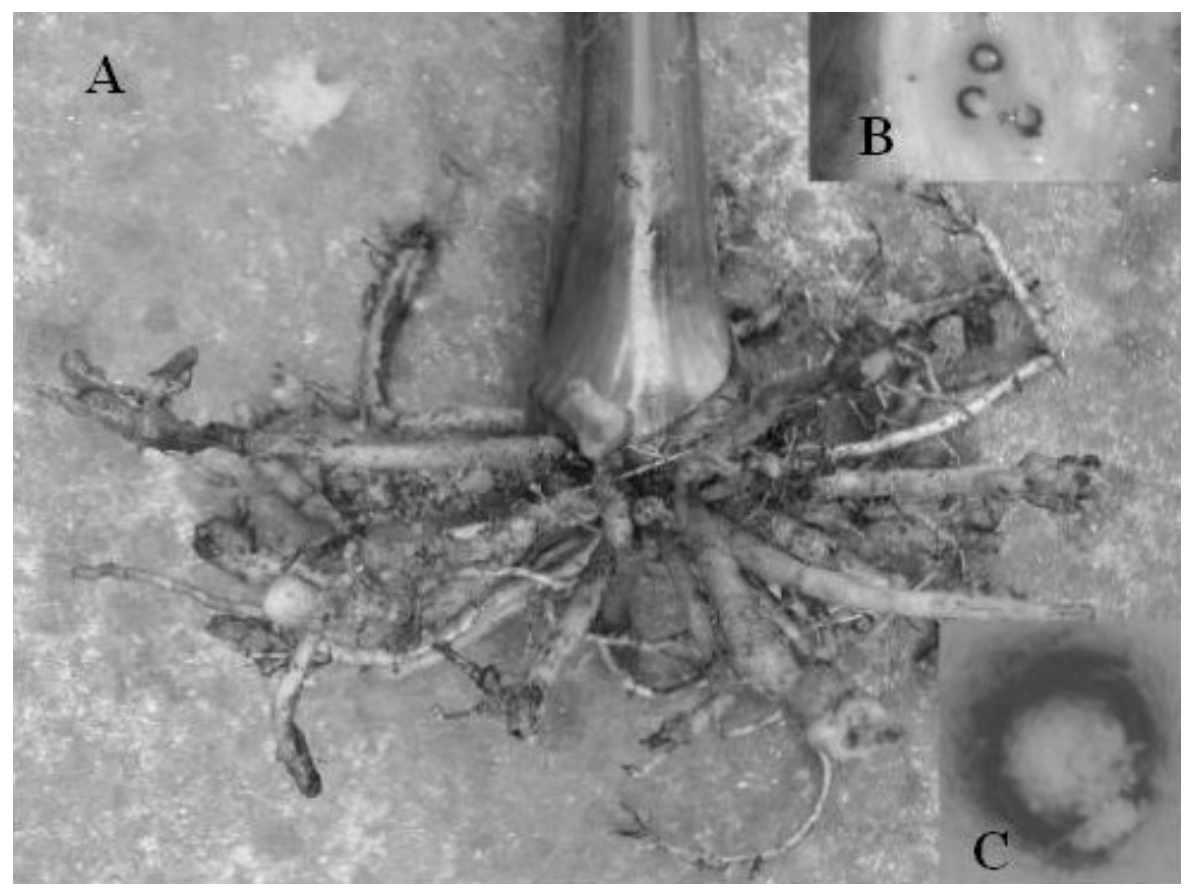

Figure 1. Infection of banana root by Meloidogyne spp: A Galls at the root tips; B Longitudinal gall section indicating the sites of females with egg masses; C Egg mass inside the root tissue. 


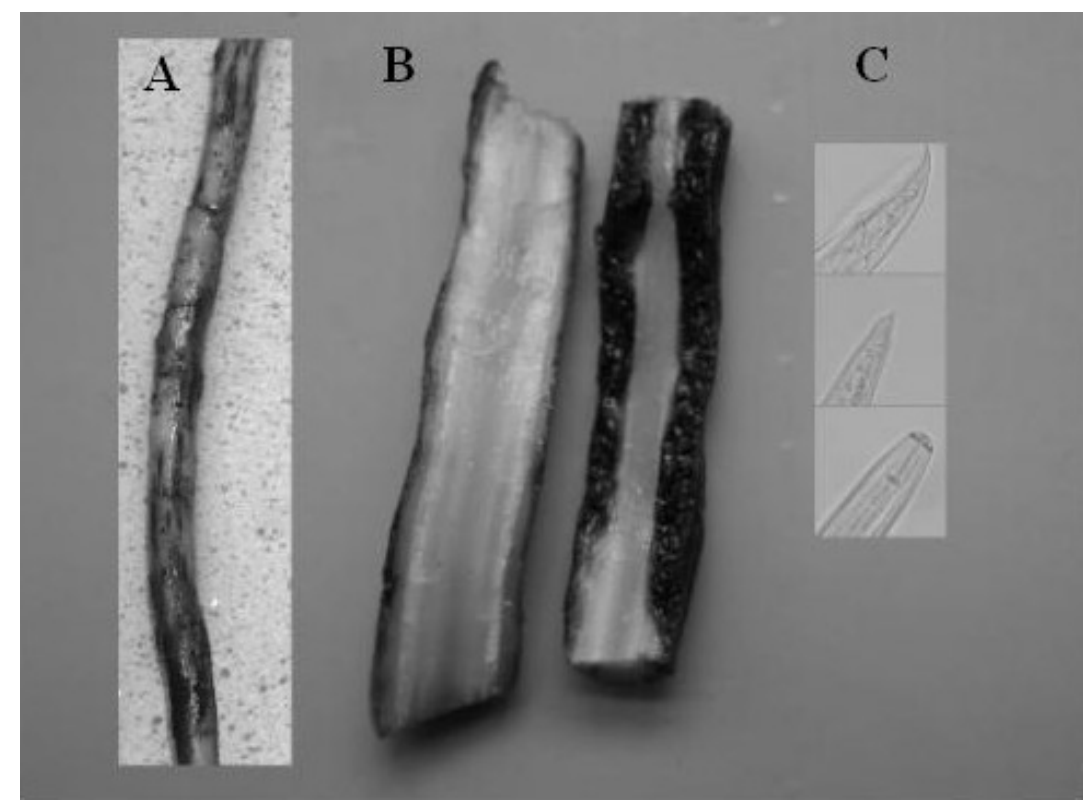

Figure 2. Infection of banana root by Pratylenchus goodeyi: A Lesions on the root surface; B Longitudinal section of healthy (left) and infected (right) root; C Male tail, female tail and female head (top to bottom).

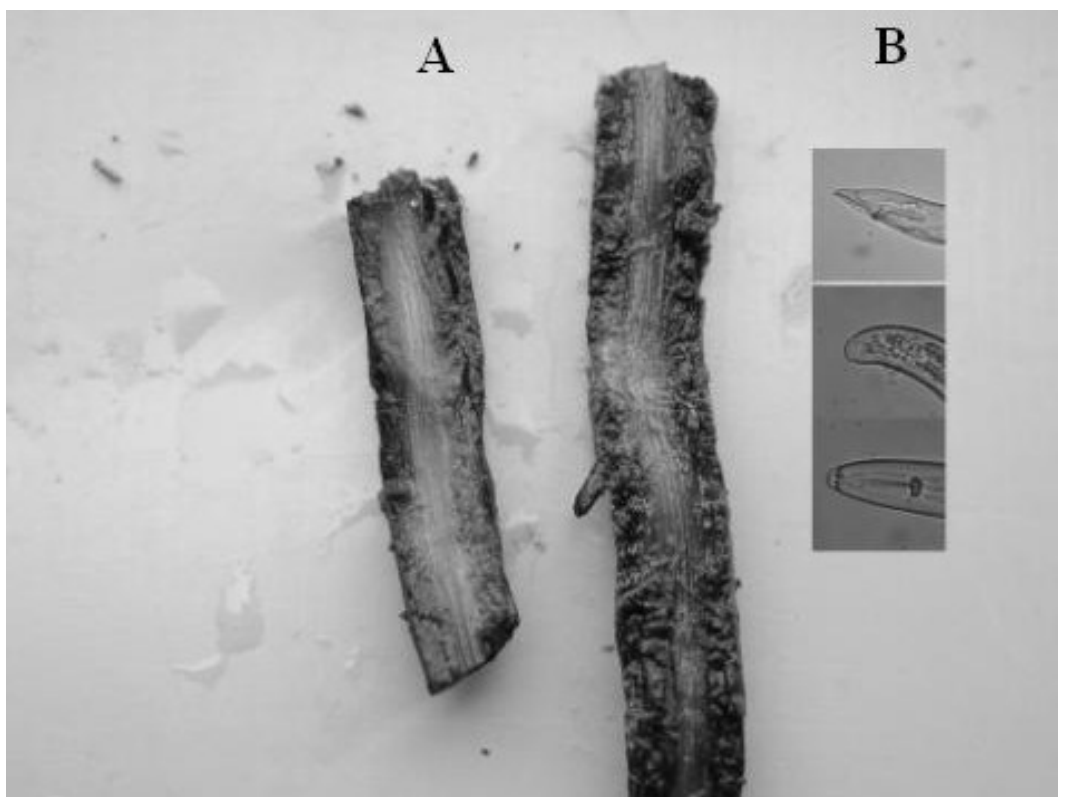

Figure 3. Infection of banana root by Helicotylenchus multicinctus : A Longitudinal section of infected roots; B Male tail, female tail and female head (top to bottom). 
TZORTZAKAKIS, E. A.: Plant parasitic nematodes associated with banana crop... 101

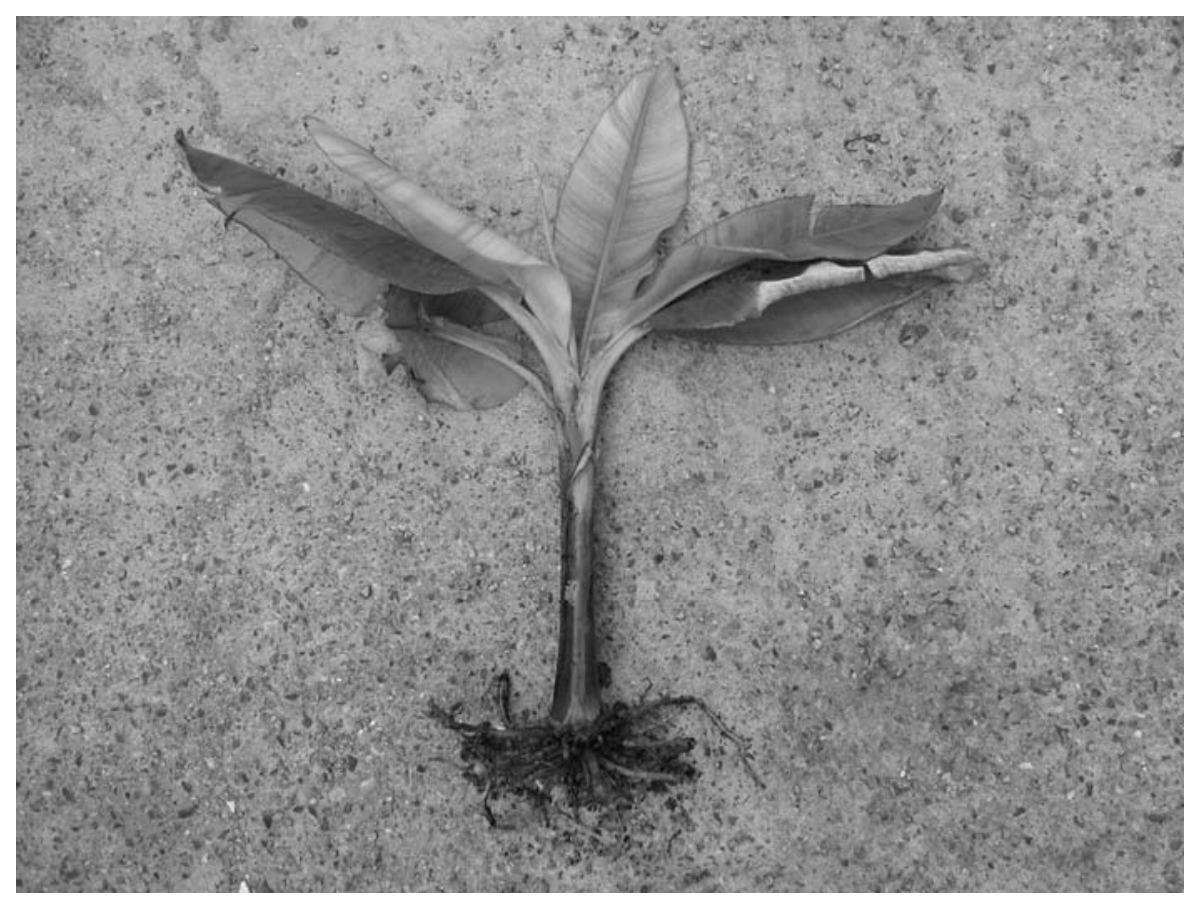

Figure 4. A young stunted and chlorotic banana plant due to infection by rootknot nematodes. 